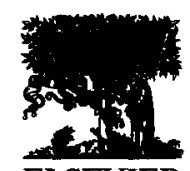

\title{
Anthelmintic resistance in nematode parasites from goats in Spain
}

\author{
J.A. Requejo-Fernández a , A. Martínez ${ }^{\text {b }}$, A. Meana ${ }^{a}$, \\ F.A. Rojo-Vázquez ${ }^{\text {c }}$, K. Osoro ${ }^{b}$, L.M. Ortega-Mora ${ }^{\text {a, * }}$ \\ ${ }^{a}$ Dpto. Patología Animal ( (Sanidad Animal), Facultad de Veterinaria, Universidad Complutense de Madrid. \\ Ciudad Universitaria s / $n, 28040$ Madrid, Spain \\ ${ }^{\mathrm{b}}$ C.I.A.T.A., Apdo. 13, 33300 Villaviciosa, Asturias, Spain \\ ${ }^{c}$ Dpto. Patología Animal (Sanidad Animal), Facultad de Veterinaria, \\ Universidad de León, 24071 León, Spain
}

Received 22 November 1996; accepted 24 March 1997

\begin{abstract}
In a flock of cashmere goats sited in Asturias (NW, Spain) diminished efficacy was observed following treatment with netobimin and consequently a study to demonstrate the existence of anthelmintic resistance and the species of nematode involved was conducted. Results from faecal egg count reduction tests before and after treatment with netobimin or ivermectin showed efficacies of 89.4 (81.8-94.8) and 99.7\% (93.9-99.9\%), respectively. Teladorsagia circumcincta was found to be the dominant species involved in netobimin resistance. Effective dose $\left(E_{50}\right)$ values in the egg hatch assay of $0.22 \mu \mathrm{g}$ thiabendazole $\mathrm{ml}^{-1}$ confirmed the existence of benzimidazole carbamate resistant nematodes. To the best of our knowledge, this is the first report on the existence of anthelmintic resistant nematodes from ruminants in Spain. (C) 1997 Elsevier Science B.V.
\end{abstract}

Keywords: Goat; Drug resistance; Teladorsagia circumcincta

\section{Introduction}

During the past 15 years, there have been increasing numbers of reports of anthelmintic resistance in goats from several countries including Australia (Barton et al., 1985), New Zealand (McKenna et al., 1990), Cameroon (Ndamukong and Sewell,

${ }^{*}$ Corresponding author. Tel.: +34-1-3943713; fax: +34-1-3943908; e-mail: luisucm@eucmax.sim.ucm.es 
1992), Kenya (Mwamachi et al., 1995), India (Yadav and Uppal, 1992) and Malaysia (Dorny et al., 1994). In Europe, nematode resistance has been described mainly in northern countries (Coles et al., 1993). By contrast, reports of anthelmintic resistance from the mediterranean basin have been scarce and mainly associated with the introduction of small ruminants from areas where anthelmintic resistance has already been detected (Himonas and Papadopoulos, 1994). Either in northern or southern countries of Europe, fibre producing goats (Cashmere and Angora goats) have been one of the principal breeds implicated in anthelmintic resistance (Jackson et al., 1992b; Varady et al., 1993).

In Spain, the dry climate in most of the country results in low levels of gastro-intestinal nematode infections and only necessitates a maximum of two anthelmintic treatments per year (Spring and Autumn). The first report of benzimidazole (mebendazole) resistance in cyathostomes of horses in Spain has recently been published (García-Pérez et al., 1994) and anthelmintic resistance has been suspected in some sheep flocks in northern Spain (Coles et al., 1993). However, until now there has been no real evidence of anthelmintic resistant nematodes in ruminants in Spain.

The three aims of the present study are first to use the faecal egg count reduction test (FECRT) to investigate the susceptibility of nematodes in goats in northern Spain to drugs within the benzimidazole and ivermectin families. The second aim of the study was to determine which species, if any, were implicated in resistance and the third was, to investigate the susceptibility of nematode ova to the benzimidazole group of anthelmintics, using the egg hatch assay (EHA).

\section{Materials and methods}

\subsection{Farm history}

During the Autumn of 1995 clinical signs of parasitic gastroenteritis were observed in a flock of cashmere goats ( 73 animals) located in Asturias (northern Spain). Following treatment of some goats with the recommended dosage of the nitrophenylguanidine compound netobimin (Hapasil $^{\circledR}, 5 \%$, Schering-Plough) a diminished treatment efficacy was observed when pre- and post-treatment coprological examination results were compared, and a more exhaustive study to demonstrate the existence of anthelmintic resistance was designed. The cashmere flock was located in an institutional farm together with a flock of sheep (Lacha and Gallega breeds) and cattle (Asturiana de los Valles breed). Cashmere goats had been introduced in December 1993 and no sign of anthelmintic resistance had been observed on the farm before this date.

\subsection{Faecal egg count reduction test}

Three groups of randomly selected cashmere does, each containing 13 animals, were used in this test. Animals included in this study had not been treated with anthelmintics during the previous 5 months. All the does were individually identified, weighed and a faecal sample taken before those in the two treated groups were dosed with netobimin 
(Hapasil ${ }^{\star}$, Schering-Plough) at $20 \mathrm{mg} \mathrm{kg}^{-1}$ (fluke recommended dose) or ivermectin (Ivomec ${ }^{\star}$, MSD Agvet) at $200 \mu \mathrm{g} \mathrm{kg}^{-1}$. Ten days after the first treatment a faecal sample was taken from all the does.

Mean faecal egg counts, percentage reductions and $95 \%$ confidence intervals were calculated by using the formulae recommended by the World Association for the Advancement of Veterinary Parasitology guidelines for detecting anthelmintic resistance in nematodes of ruminants (Coles et al., 1992). An efficacy of less than $95 \%$, and $95 \%$ confidence limits of less than $90 \%$ were taken as indicating the presence of anthelmintic resistant nematodes.

\subsection{Faecal egg count and identification of species}

Faecal samples collected from each animal were processed to determine the number of nematode eggs per gram of faeces using a modified McMaster method (MAFF. 1986). Diagnosis of nematode species present in each goat group before and after anthelmintic treatment was determined following the recommended guidelines (Coles et al., 1992).

\subsection{Egg hatch assay}

Faecal samples obtained from 12 cashmere does in the same flock were taken on day 0 , anaerobically stored at room temperature (Hunt and Taylor, 1989) and processed within two days. The egg hatch assay (Le Jambre, 1976) was performed using pure thiabendazole in nine concentrations ranging from 0.05 to $1.5 \mu \mathrm{g} \mathrm{ml}^{-1}$. Effective dose $\left(E_{50}\right)$ values were calculated using a regression analysis after correcting for natural mortality. Animals in which the $\mathrm{ED}_{50}$ value is in excess of $0.1 \mu \mathrm{g}$ thiabendazole $\mathrm{ml}^{-1}$ are considered to be carrying benzimidazole-resistant strains of nematodes.

\section{Results}

The arithmetic mean faecal egg counts $( \pm$ SD) before and after treatment with netobimin or ivermectin are given in Table 1 . Netobimin at $20 \mathrm{mg} \mathrm{kg}^{-1}$ body weight reduced the faecal egg count by $89.4 \%$ with a $95 \%$ confidence intervals of $81.8-94.8 \%$. Nematode parasites were sensitive to ivermectin with an efficacy of $99.7 \%$ and confidence intervals of $93.9-99.9 \%$.

Table 1

Mean faecal egg counts $( \pm S D)$ and efficacies from cashmere goats prior to and following anthelmintic treatments with netobimin or ivermectin

\begin{tabular}{llcc}
\hline Group & \multicolumn{2}{l}{ Mean faecal egg counts $( \pm$ SD) } & Efficacy (\%) \\
\cline { 2 - 4 } & Pre-treatment & Post-treatment & \\
\hline Control & $1355 \pm 793$ & $2185 \pm 1791$ & - \\
Netobimin treated & $1080 \pm 1130$ & $231 \pm 215$ & 89.4 \\
Ivermectin treated & $1880 \pm 1668$ & $6 \pm 17$ & 99.7 \\
\hline
\end{tabular}


Table 2

Percentages of nematode larvae present in each goat group before and after anthelmintic treatments with netobimin or ivermectin

\begin{tabular}{|c|c|c|c|c|c|c|}
\hline \multirow[t]{2}{*}{ Genera } & \multicolumn{2}{|c|}{ Control group } & \multicolumn{2}{|c|}{ Netobimin treated group } & \multicolumn{2}{|c|}{ Ivermectin treated group } \\
\hline & day 0 & day 10 & day 0 & day 10 & day 0 & day 10 \\
\hline Teladorsagia & 15 & 8 & 12 & 60 & 10 & $\mathrm{NL}$ \\
\hline Oesophagostomun & 52 & 50 & 40 & 25 & 48 & NL \\
\hline Trichostrongylus & 10 & 10 & 13 & 15 & 8 & NL \\
\hline Haemonchus & 13 & 18 & 22 & 0 & 18 & NL \\
\hline Chabertia & 10 & 14 & 13 & 0 & 16 & NL \\
\hline Total & 100 & 100 & 100 & 100 & 100 & NL \\
\hline
\end{tabular}

NL: no larvae

The results from the faecal culture and larval identification, representing the nematode genera present in the different doe groups on days 0 and 10 , are shown in Table 2 . In does in the netobimin treated group, the genera present before treatment were Oesophagostomum (40\%) and Haemonchus (22\%), with smaller numbers of Chabertia (13\%), Trichostrongylus (13\%) and Teladorsagia (12\%). After treatment with netobimin the predominant genus was Teladorsagia (60\%), followed by Oesophagostomum (25\%) and Trychostrongylus (15\%).

The $\mathrm{ED}_{50}$ value obtained after probit analysis of data in the EHA was $0.22 \mu \mathrm{g}$ thiabendazole $\mathrm{ml}^{-1}$, demonstrating the presence of benzimidazole resistant nematodes based on the interpretations of Le Jambre (1976).

\section{Discussion}

The results from the FECRT and the EHA both provided evidence for the presence of benzimidazole resistant, but ivermectin susceptible populations of nematodes in goats from North of Spain (Asturias). This is the first report on the existence of anthelmintic resistant nematodes from ruminants in this country.

Studies of the efficacy of benzimidazoles in goats (Pomroy, 1996) suggest that it may be better to treat goats with drugs in the benzimidazole family at one-and-a-half or twice the recommended dosage. For instance, Bogan et al. (1987) found only a $42 \%$ bioavailability of oxfendazol in goats when compared with sheep after oral administration but no after intravenous administration. The dosage of netobimin used in the FECRT was the fluke recommended dose which is 2.6 times the recommended dose rate for gastro-intestinal nematodes.

In this study, Teladorsagia was the main genera involved in resistance. $T$. circumcincta is one of the most prevalent specie parasitising small ruminants in Spain (Compairé Fernández and Tarazona Vilas, 1985), while benzimidazoles are the most frequently used anthelmintics in this country (Coles et al., 1993). The results are in accordance with studies in Scotland in goats and sheep which have shown Teladorsagia species to have the greatest propensity for developing resistance to the benzimidazoles 
(Jackson et al., 1992a), while in England, T. circumcincta seems to be the main species in sheep and Haemonchus contortus in goats (Hong et al., 1996). The presence in the post-treatment larval cultures of Oesophagostomum and Trichostrongylus suggests either the possibility of resistance in these species or a lower efficacy of netobimin against these species. Further studies are required in order to clarify the situation in goats.

There could be two main reasons for the existence of anthelmintic resistance in this cashmere flock. First, goats could have acted as carriers of anthelmintic resistant strains of nematodes since they were originally imported from the UK, where a high prevalence of anthelmintic resistance in fibre producing goats has been recorded (Jackson et al., 1992b; Hong et al., 1996). The other possibility is the acquisition of resistance once the animals arrived in Spain. Although the prevailing climatic conditions in this part of Spain favour a continuous cycle of infection between the host and the pasture, the low frequency of anthelmintic treatments (2-3 annual treatments, alternating benzimidazoles and ivermectin), the limited time the cashmere goats were on the farm and the absence of diminished anthelmintic efficacy in other sheep and goat flocks in the area support the idea of imported anthelmintic resistance.

The existence of resistant strains of nematodes in breeding animals from an institutional farm increases the risk of propagation of resistance (Coles and Roush, 1992) and livestock movement, in or between countries, has been suggested as one of the principal mechanisms of resistance propagation (Varady et al., 1993; Dorny et al., 1994; Himonas and Papadopoulos, 1994). Animal movement presents a particular risk for Spanish sheep and goat flocks since small ruminants harbour the same species of nematodes, anthelmintic resistance is retained after passage through sheep and a large number of Spanish sheep flocks also contain small numbers of goats.

In conclusion, this study demonstrates the need to investigate the prevalence of anthelmintic resistance in Spain. Results from this and similar studies (Varady et al., 1993; Himonas and Papadopoulos, 1994) show that investigation of resistant strains of nematodes may be required not only in animals imported from countries outside the EU, but also from EU countries with a previous record of anthelmintic resistance.

\section{Acknowledgements}

This work was supported by the SC93-193-C2 project from the Spanish Ministry of Agriculture and Fisheries.

\section{References}

Barton, N.J., Trainor, B.L., Urie, J.S., Atkins, J.W., Pyman, M.F.S., Wolstencroft, I.R., 1985. Anthelmintic resistance in nematode parasites of goats. Aus. Vet. J. 62, 224-227.

Bogan, J., Benoit, E., Delatour, P., 1987. Pharmacokinetics of oxfendazole in goats: A comparison with sheep. J. Vet. Pharmacol. Therap. 10, 305-309.

Coles, G.C., Bauer, C., Borgsteede, F.H.M., Geerts, S., Klei, T.R., Taylor, M.A., Waller, P.J., 1992. World association for the advancement of veterinary parasitology (W.A.A.V.P.) methods for the detection of anthelmintic resistance in nematodes of veterinary importance. Vet. Parasitol. 44, 35-44. 
Coles, G.C., Borgsteede, F.H.M., Geerts, S. (Eds.), 1993. Anthelmintic resistance in nematodes of farm animals. Proc. of a Seminar Organised for the Eur. Commission, 8-9 November at Brussels, Belgium.

Coles, G.C., Roush, R.T., 1992. Slowing the spread of anthelmintic resistant nematodes of sheep and goats in the United Kingdom. Vet. Rec. 130, 505-510.

Compairé Fernández, C., Tarazona Vilas, J.M. (Eds.), 1985. Las parasitosis de los rumiantes en pastoreo en España. Comunicaciones I.N.I.A. (serie Higiene y Sanidad Animal), No. 11. Ministerio de Agricultura Pesca y Alimentación.

Dorny, P., Claerebout, E., Vercruysse, J., Sani, R., Jalila, A., 1994. Anthelmintic resistance in goats in peninsular Malaysia. Vet. Parasitol. 55, 327-342.

García-Pérez, A.L., Muñoz, F., Povedano, I., Juste, R.A., 1994. Estrongilosis en el ganado equino I. Sobre un caso de resistencia de los ciatostomas al mebendazol. Med. Vet. 11, 30-35.

Himonas, C., Papadopoulos, E., 1994. Anthelmintic resistance in imported sheep. Vet. Rec. 134, 456.

Hong, C., Hunt, K.R., Coles, G.C., 1996. Occurrence of anthelmintic resistant nematodes on sheep farms in England and goat farms in England and Wales. Vet. Rec. 139, 83-86.

Hunt, K.R., Taylor, M.A., 1989. Use of the egg hatch assay on sheep faecal samples for the detection of benzimidazole resistant nematodes. Vet. Rec. 125, 153-154.

Jackson, F., Jackson, E., Coop, R.L., 1992a. Evidence of multiple anthelmintic resistance in a strain of Teladorsagia circumcincta (Ostertagia circumcincta) isolated from goats in Scotland. Res. Vet. Sci. 53, 371-374.

Jackson, F., Jackson, E., Little, S., Coop, R.L., Russel, A.J.F., 1992b. Prevalence of anthelmintic-resistant nematodes in fibre-producing goats in Scotland. Vet. Rec. 131, 282-285.

Le Jambre, L.F., 1976. Egg hatch as an in vitro assay of thiabendazole resistance in nematodes. Vet. Parasitol. 2, 385-391.

Ministry of Agriculture, Fisheries and Food (MAFF), 1986. Manual of Veterinary Parasitological Laboratory Techniques. Reference book 418, HMSO, London.

McKenna, P.B., Badger, S.B., McKinley, R.L., Taylor, D.E., 1990. Simultaneous resistance to two or more broad-spectrum anthelmintics by gastrointestinal nematode parasites of sheep and goats. New Zeal. Vet. J. $38,114-117$.

Mwamachi, D.M., Audho, J.O., Thorpe, W., Baker, R.L., 1995. Evidence for multiple anthelmintic resistance in sheep and goats reared under the same management in coastal Kenya. Vet. Parasitol. 60, 303-313.

Ndamukong, K.J.N., Sewell, M.M.H., 1992. Resistance to benzimidazole anthelmintics by trichostrongyles in sheep and goats in North-West Cameroon. Vet. Parasitol. 41, 335-339.

Pomroy, W.E., 1996. Anthelmintic resistance in goats. VI International Conference on goats. 6-11 May, Beijing, China. pp. 717-726.

Varady, M., Praslicka, J., Corba, J., Vesely, L., 1993. Multiple anthelmintic resistance of nematodes in imported goats. Vet. Rec. 132, 387-388.

Yadav, C.L., Uppal, R.P., 1992. Levamisole resistant Haemonchus contortus in goats. Vet. Rec. 130, 228. 